\title{
Valsartan in combination with metformin and gliclazide in diabetic rat model using developed RP-HPLC method
}

\author{
Rasmita Patra, Yedukondalu Kollati, Sampath Kumar NS and Vijaya R. Dirisala* (1)
}

\begin{abstract}
Background: Oral administration of biguanides (metformin) and sulfonylureas (gliclazide) are the most common approach of management of type 2 diabetes in humans. Among these diabetic patients, approximately 40-60\% suffers from hypertension. Hence, the need of the day is application of polytherapy. A major challenge in polytherapy is the drug-drug interactions that may arise. Hence, this study is focused to develop a reverse phase high-performance liquid chromatography (RP-HPLC) method for concurrent estimation of diabetic drug metformin and hypertension drug valsartan using C18 column and find any possible pharmacokinetic interactions between the two drug combinations strategies, i.e., metformin-valsartan and gliclazide-valsartan in streptozotocin-induced diabetic rats.

Result: The bioanalysis of drug-drug interaction pharmacokinetic result showed no significant difference in the $t_{\max }$ of single treatment of gliclazide and single treatment of metformin or upon co-administration with valsartan.

Conclusion: Our study has shown that polytherapy of valsartan, a drug administered for hypertension along with hypoglycemic drugs metformin and gliclazide, can be advantageous and safe in patients suffering from both diabetes and hypertension.
\end{abstract}

Keywords: RP-HPLC, Metformin, Valsartan, Gliclazide, Hypertension, Diabetes mellitus

\section{Background}

Diabetes has become a growing epidemic, and the percentage of patient population is increasing in leaps and bounds [1]. It is a chronic condition of metabolic disorder featured by elevated glucose level in blood circulation [2]. This is due to the improper alteration in regulation of protein, carbohydrate, and lipid metabolism [3], due to reduction in glucose uptake by skeletal muscle cells and uncontrolled hepatic glucose output. Based on insulin secretion, diabetes can be classified under two major categories: types 1 and 2, where type 1 is insulin dependent, whereas type 2 is non-insulin dependent [4]. The concern among diabetic patients is the multi organ damage that happens in course of the

\footnotetext{
*Correspondence: drdirisala@gmail.com

Department of Biotechnology, Vignan's University (Deemed to be), Guntur, AP 522213, India
}

\section{Springer Open}

disease if left undetected or untreated. Such patients require polytherapy wherein drug-drug interactions may lead to adverse side effects $[5,6]$. Besides mortality, the therapeutic effect of either drug may lower or enhance or may execute new activity which was not observed in earlier therapeutic studies [7].

Metformin, the first known line of therapy for type 2 diabetes, acts by reducing the rate of gluconeogenesis and enhances sensitivity of insulin [8], reducing free fatty acids (FFA) through adipose tissue inhibition [9]. It also showed therapeutic effect on obesity metabolic disorder [10]. Women, who suffer from polycystic ovary syndrome (PCOS), sometimes rely on this drug for ovulation and regular menstrual cycle [11, 12]. The chemical structure of metformin is shown in Fig. 1. Apart from metformin, another drug, i.e., a sulfonylurea, gliclazide is frequently prescribed to control type 2 diabetes. 


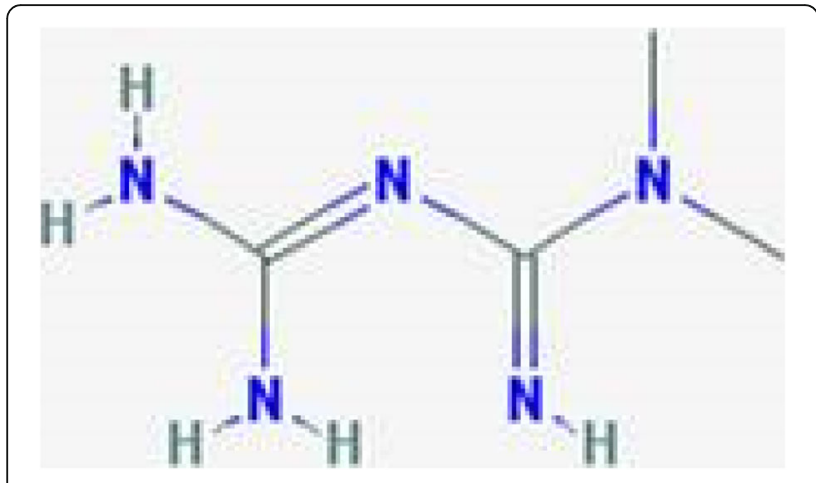

Fig. 1 Structure of metformin

Gliclazide is known to shield pancreatic beta cell apoptosis induced due to hyperglycemia [13-15] and its therapeutic effect on plaque formation in arteries, thereby reducing atherogenesis in hyperglycemic patients [16].

The prevalence of hypertension among diabetic patients is very high, accounting to $75 \%$ of coexistence [17]. Valsartan, an angiotensin II receptor blocker, is the common treatment option for hypertension [18]. The chemical structure of valsartan is shown in Fig. 2. Since these patients are subjected to polytherapy, there arise possibilities of occurrences of interactions between valsartan-metformin and valsartan-gliclazide. Hence, our study is aimed to look for possible drug interaction effect of antihypertensive drug valsartan along with metformin. Hence, RP-HPLC method is developed, which can be applied for routine laboratory analysis, forced degradation studies, and pharmacokinetic studies (as well as in laboratory analysis, forced degradation studies). In our previous study, we had developed a method (RP-HPLC) for concurrent estimation of gliclazide and valsartan [19].

Clinical studies illuminating drug-drug interaction is an important parameter for polytherapy. Various studies have thrown light on drug-drug interactions of which one of the studies has shown reduced hypoglycemic effect of gliclazide upon prolonged co-administration with

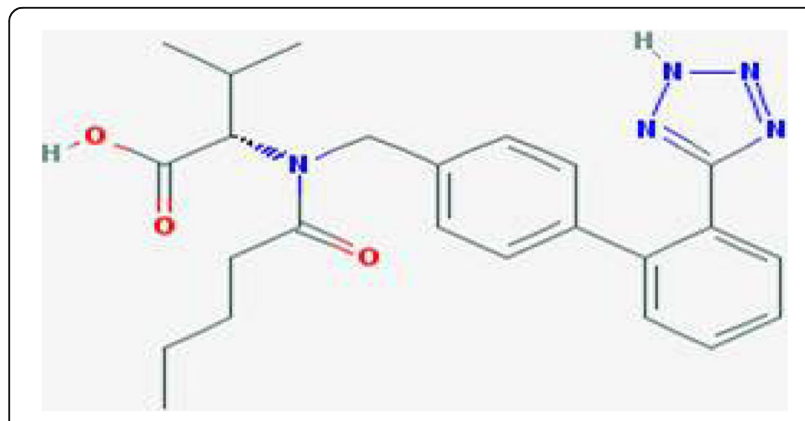

Fig. 2 Structure of valsartan anti-hypertensive drug lisinopril [20, 21]. An in vivo study in diabetic rat and rabbit revealed synergistic effect of gliclazide upon co-administration with antihyperlipidemic drug pravastatin [22]. Another study by Patel and Kothari revealed no drug-drug interaction between pitavastatin (cholesterol-lowering drug) and candesartan (anti-hypertensive drug) [23]. In this study, we have focused on the effects of valsartan with either gliclazide or metformin by concomitant administration in diabetic rats.

\section{Materials}

\section{Ethical approval}

All experimental procedures and protocols used in the animal study were reviewed and approved by the Institutional Animal Ethical Committee (IAEC/1657/CMRCP/ T2/PH), Vijaya College of Pharmacy, Hyderabad, Telangana, India.

Torrent Pharmaceutical Ltd., Ahmedabad, supplied valsartan, gliclazide, and metformin. The working standard was kindly provided by Lupin Pharma, India. All other reagents were procured from E. Merck, (India) Ltd., and are HPLC grade. The D-glucose GOD-POD colorimetric assay kit was supplied by Excel Diagnostic Center, Hyderabad. Streptozotocin was obtained from Sigma.

\section{Methods}

\section{Parameters of chromatography}

The HPLC from Waters Company was integrated with $\mathrm{XTerra}^{\circ} \mathrm{C} 18$ column of $5 \mu \mathrm{m}$ (with features 4.6X250 $\mathrm{mm}$ ) for separation. Mobile phase was fixed to mixture of phosphate buffer and methanol in 60:40 ratio, and the rate of flow was $1 \mathrm{~mL} \cdot \mathrm{min}^{-1}$. The filtration of the mobile phase was performed by using a $0.2-\mu \mathrm{m}$ membrane filter. Chromatographic procedure was performed at RT.

\section{Preparation of standard solutions}

To prepare standards, metformin and valsartan were each weighed $100 \mathrm{mg}$ and added into $10 \mathrm{~mL}$ of a solvent which is a mixture of phosphate buffer and methanol in 60:40 ratio. By adding another $15 \mathrm{~mL}$ of phosphate buffer and methanol solution, the final volume was made up to $25 \mathrm{~mL}$. The stock solution was subjected to sonication for $15 \mathrm{~min}$, and by mixing $75 \mathrm{~mL}$ of diluent, the volume was made up to $100 \mathrm{~mL}$ to achieve a $1 \mathrm{mg} / \mathrm{mL}$ stock solution. Standard stock solution was diluted to achieve 2 to $20 \mu \mathrm{g} \cdot \mathrm{ml}^{-1}$ as final concentration for valsartan, whereas metformin final concentration was set to 3.12 to $100 \mu \mathrm{g} \cdot \mathrm{ml}^{-1}$.

\section{Validation of the method}

The following RP-HPLC parameters were validated as per ICH guidelines [24]. 


\section{Linearity}

The standard (metformin and valsartan) stock solutions were diluted with mobile phase. The final concentration of valsartan was in the range of 2 to $20 \mu \mathrm{g} \cdot \mathrm{ml}^{-1}$ whereas the final concentration of metformin was 3 to $100 \mu \mathrm{g} \cdot \mathrm{ml}^{-1}$. A volume of $20 \mu \mathrm{L}$ was injected into C18 column. The calibration graph was achieved by peak area on $\mathrm{Y}$-axis versus concentration of valsartan and metformin on $\mathrm{X}$-axis.

\section{Accuracy}

Accuracy was validated in triplicate by addition of three different amounts of valsartan and metformin to previously analyzed samples. The quantities of analytes recovered were compared with the quantities of drugs injected. The quantities added were equivalent to 50, 100 , and $150 \%$ of the amount originally presented.

\section{Precision}

To evaluate precision, 6 tests of both the drugs of 10 and $30 \mu \mathrm{g} \cdot \mathrm{ml}^{-1}$ were injected into the column. This procedure was performed on a single day (which is also called intraday precision) as well as on three different days (which is also called intermediate precision).

\section{Limit of detection and quantitation}

The minimum concentrations of each drug which was able to produce LOD was minimum $\mathrm{S} / \mathrm{N}$ of 3 . The minimum quantity of each drug was quantified by this method is called LOQ.

\section{Method applicability and system suitability}

The devised method was validated by applying pharmaceutical dosage forms for the estimation of valsartan and metformin, to evaluate the system suitability. The analytical procedure of the system was carried out by performing system suitability tests. Various parameters were evaluated such as theoretical plate number $(\mathrm{N})$, tailing

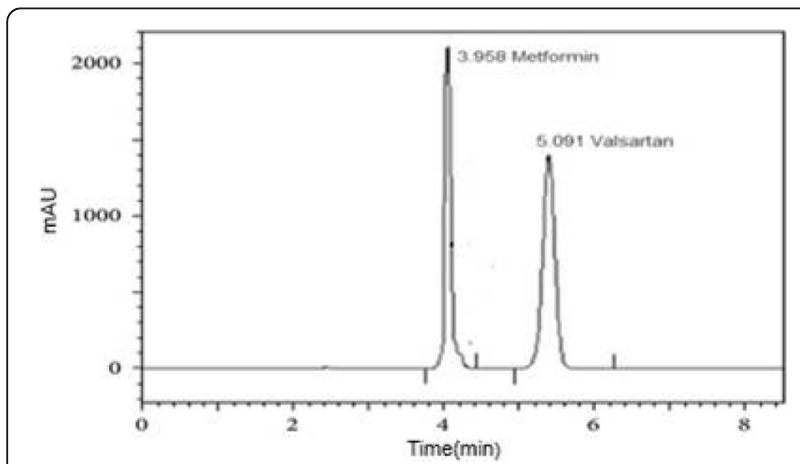

Fig. 3 Typical chromatogram of valsartan and metformin was obtained by injecting $20 \mu \mathrm{L}$ of each drug solution with flow rate 1 $\mathrm{mL}$ per minute performed with UV detector at $238 \mathrm{~nm}$.
Table 1 System suitability: metformin-valsartan

\begin{tabular}{lll}
\hline S. No. & Metformin $\left(\mathbf{3 0} \boldsymbol{\mu} \cdot \mathbf{m l}^{-\mathbf{1}}\right)$ & Valsartan $\left(\mathbf{1 0} \boldsymbol{\mu g} \cdot \mathbf{m l}^{\mathbf{- 1}}\right)$ \\
\hline 1 & 30.019 & 9.420 \\
2 & 29.168 & 9.159 \\
3 & 28.839 & 9.238 \\
4 & 29.139 & 9.550 \\
5 & 29.05 & 9.289 \\
6 & 28.939 & 9.150 \\
Standard deviation & 0.423 & 0.157 \\
Mean & 29.192 & 9.301 \\
CV (\%) & $\mathbf{1 . 4 5 0}$ & $\mathbf{1 . 6 8 8}$ \\
Accuracy (\%) & $\mathbf{9 7 . 3 1}$ & $\mathbf{9 3 . 0 1}$
\end{tabular}

$\mu \mathrm{g} . \mathrm{ml}^{-1}$, microgram per milliliter; $\% \mathrm{CV}$, the percentage of coefficient of variation

factor, retention time, resolution, area, and \% peak area were analyzed. Twenty microliters of the working standard solution of valsartan $\left(10 \mu \mathrm{g} \cdot \mathrm{ml}^{-1}\right)$ and metformin $\left(25 \mu \mathrm{g} \cdot \mathrm{ml}^{-1}\right)$ was injected into the column for 6 times.

\section{Analyzed method specificity}

It was monitored to achieve clear peaks for both the drugs avoiding interference (from drug impurities or solvents) by the proposed method.

\section{Robustness}

To execute the robustness of designed method, analyzed standard concentrations $(\mathrm{n}=6)$, i.e., $10 \mu \mathrm{g} / \mathrm{mL}$ of valsar$\tan$ and $30 \mu \mathrm{g} / \mathrm{mL}$ of metformin, were done using two different columns of the same make.

\section{Pharmacokinetic study}

Male Wistar rats were obtained from Vab Bioscience, Hyderabad, India, with the approval of Committee for the Purpose of Control and Supervision of Experiments (282/PO/RcBt/2000/CPCSEA). Starved (12 h) animals (male Wistar rats) were induced with diabetes by injecting freshly prepared streptozotocin of 0.220 to $0.250 \mathrm{~mL}$ (60.0 mg streptozotocin dissolved in $1 \mathrm{~mL}$ of $0.010 \mathrm{M}$ Citrate buffer, $\mathrm{pH} 4.5)$ intraperitoneally amounting to dose of $60 \mathrm{mg} \cdot \mathrm{kg}^{-1}$ as the final one. The animals were handled as per the approved protocol of Institutional Animal Ethical Committee. Prior to the induction of diabetes, animals were placed in optimum conditions with atmospheric humidity of $50.0 \%$ and supplemented with pellet diet and water ad libitum. The hyperglycemic condition was assessed by measuring the concentration of glucose in non-fasting serum post $48 \mathrm{~h}$ of induction. Total of six groups were made, i.e., four groups of individual treatment of gliclazide, metformin and valsartan (to diabetic as well as healthy rats). To the remaining groups, combination treatment is given, i.e., gliclazide 
(a)

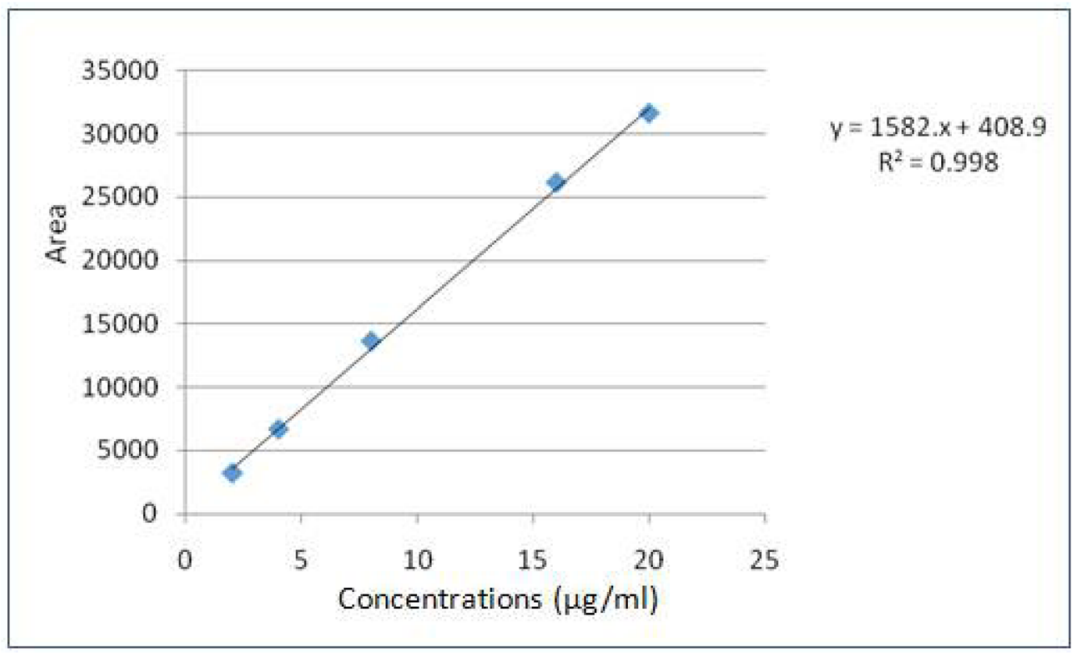

(b)

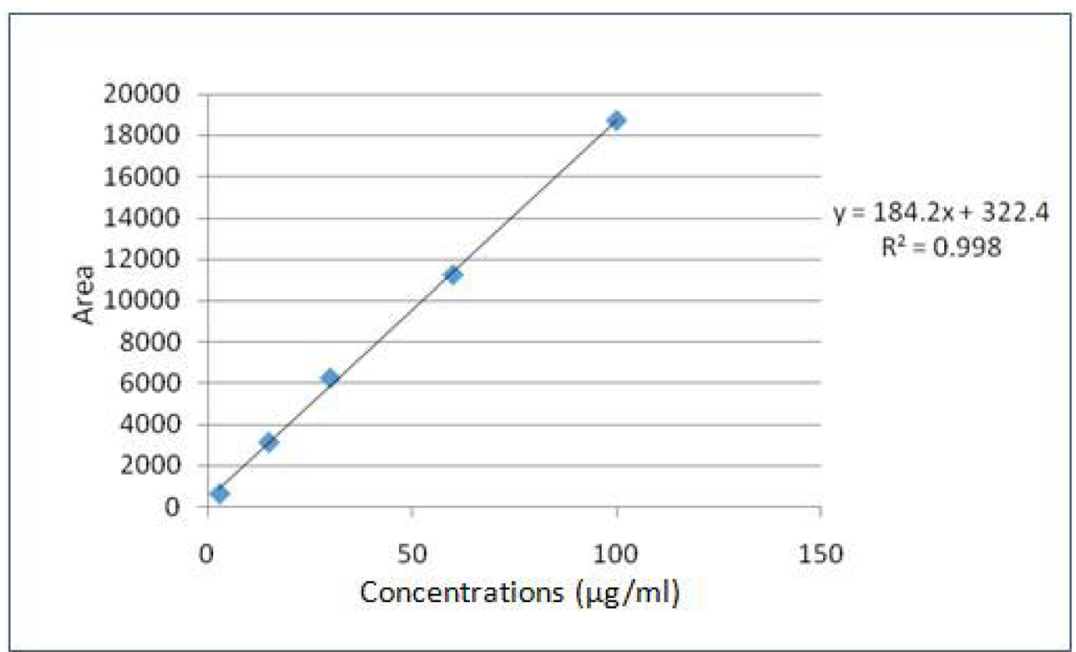

Fig. 4 a Calibration curve of valsartan. b Calibration curve of metformin.

and valsartan, and metformin and valsartan were administered to diabetic rats. Plasma sample segregates from blood were obtained at different time intervals (zero (0), $1,2,4,6,8$, till $24 \mathrm{~h}$ ) post drug administration.

The plasma samples were processed for HPLC analysis. All the samples were evaluated using reverse phase HPLC method developed by us. Phenformin $(10 \mu \mathrm{L}$ of $40 \mu \mathrm{g} / \mathrm{mL}$ ) was used as an internal standard. Twenty microliter of supernatant was injected into C18 column to estimate gliclazide and valsartan individually and together. The chromatographic conditions were set with mobile phase acetonitrile (45:55); phosphate buffer $\mathrm{pH}$ was set at 4.80 , and pressure was set at 190 to $210 \mathrm{kg.f} /$ $\mathrm{cm}^{3}$; flow rate was set at one $\mathrm{mL} \cdot \mathrm{min}^{-1}$; procedure was performed at room temperature; and UV detector wavelength was set at $234 \mathrm{~nm}$ [19]. To estimate metformin and valsartan in rat plasma simultaneously, the chromatographic conditions such as mobile phase was set at phosphate buffer $(\mathrm{pH} 4)$, acetonitrile $60: 40 \mathrm{v} / \mathrm{v}$ respectively; pressure was set at 190 to $210 \mathrm{~kg} . \mathrm{f} / \mathrm{cm}^{3}$; flow rate was set at $1 \mathrm{~mL} \cdot \mathrm{min}^{-1}$; procedure was performed at RT; UV detector was set at wavelength of $238 \mathrm{~nm}$; and injection volume was $20 \mu \mathrm{L}$. Various concentrations such as $0.050,0.10,0.50,1.0,5.0,10.0,20.0$, and $40.0 \mu \mathrm{g} . \mathrm{ml}^{-1}$ of metformin, gliclazide and valsartan were prepared using rat plasma for standard calibration curve. The peak area of all three drugs (metformin, gliclazide, and valsartan) was recorded for further analysis. Animals were sacrificed by deep burial, following cervical dislocation. 
Table 2 System suitability: valsartan-metformin

\begin{tabular}{|c|c|c|c|c|c|}
\hline \multirow[t]{2}{*}{ Valsartan } & \multirow[t]{2}{*}{ Concentrations $\left(\mu \mathrm{g} \cdot \mathrm{ml}^{-1}\right)$} & \multicolumn{4}{|l|}{ Area } \\
\hline & & 1 & 2 & 3 & Average \\
\hline & 2.00 & 3209.00 & 3235.00 & 3141.00 & 3195.00 \\
\hline & 4.00 & 6597.00 & 7053.00 & 6329.00 & 6660.00 \\
\hline & 8.00 & 13978.00 & 13964.00 & 12910.00 & 13617.00 \\
\hline & 16.00 & 26973.00 & 26949.00 & 24405.00 & 26109.00 \\
\hline & 20.00 & 32056.00 & 31936.00 & 30782.00 & 31591.00 \\
\hline & Intercept & 346.410 & 588.730 & 291.420 & 408.850 \\
\hline & Slope & 1621.00 & 1603.00 & 1522.00 & 1582.00 \\
\hline & Standard deviation & & & & 158.186 \\
\hline & LOQ ( $\left.\mu \mathrm{g} \cdot \mathrm{ml}^{-1}\right)$ & & & & 0.999 \\
\hline & $\operatorname{LOD}\left(\mu \mathrm{g} \cdot \mathrm{ml}^{-1}\right)$ & & & & 0.329 \\
\hline \multirow[t]{12}{*}{ Metformin } & Concentrations $\left(\mu \mathrm{g} \cdot \mathrm{ml}^{-1}\right)$ & Area & & & \\
\hline & & 1 & 2 & 3 & Average \\
\hline & 3.00 & 625.00 & 623.00 & 624.00 & 624.00 \\
\hline & 15.00 & 3125.00 & 3115.00 & 3120.00 & 3120.00 \\
\hline & 30.00 & 6250.00 & 6230.00 & 6240.00 & 6240.00 \\
\hline & 60.00 & 11250.00 & 11214.00 & 11232.00 & 11232.00 \\
\hline & 100.00 & 18750.00 & 18690.00 & 18720.00 & 18720.00 \\
\hline & Intercept & 322.900 & 321.900 & 322.400 & 322.400 \\
\hline & Slope & 184.50 & 183.90 & 184.20 & 184.200 \\
\hline & Standard deviation & & & & 0.5 \\
\hline & LOQ $\left(\mu \mathrm{g} \cdot \mathrm{ml}^{-1}\right)$ & & & & 0.027 \\
\hline & LOD $\left(\mu \mathrm{g} \cdot \mathrm{ml}^{-1}\right)$ & & & & 0.008 \\
\hline
\end{tabular}

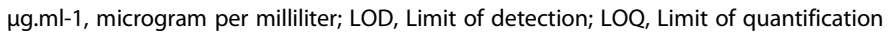

\section{Statistical analysis}

For analysis, the Win Nonlin ${ }^{\ominus} 5.1$ software was used. The pharmacokinetic units such as highest plasma concentrations achieved $\left(C_{\max }\right), t_{\max }$ denotes time for achievement of maximum concentration, the area under the curve is represented by AUC, and $t^{1 / 2}$ represents elimination half-life, whereas $\mathrm{AUC}_{0-\mathrm{t}}$ denotes the area the under the curve between time 0 to $24 \mathrm{~h}$, while $\mathrm{AUC}_{0-\alpha}$ represents the area under the curve from time at $0 \mathrm{~h}$ to infinity. Pharmacokinetic and pharmacodynamic statistical comparisons between individual and in combination of anti-diabetic drugs, which were used in this study, i.e., metformin and gliclazide and antihypertensive drug valsartan, were evaluated using students paired t test. Statistical significance was considered to be $\mathrm{P}<0.05$. Mean \pm S.E.M was determined to decipher the relationship between total plasma concentrations and pharmacokinetic and pharmacodynamic parameters.

\section{Results}

Method development and validation

The developed method is robust for the simultaneous evaluation of both metformin and valsartan. For optimization of chromatographic conditions, buffering systems of various combinations were tested such as acetonitrile-methanol, methanol-water, and acetonitrilewater. The other parameters were also taken into consideration for optimization such as detection wavelength, flow rate, volume of injection, and temperature. At wavelength of $238 \mathrm{~nm}$, both valsartan and metformin analytes were found to be free from interferences and the peaks were well defined. Typical chromatograms of metformin and valsartan are shown in Fig. 3.

\section{System suitability}

The system suitability pertaining to the proposed method was performed by applying 6 injections (metformin of $30 \mu \mathrm{g} \cdot \mathrm{ml}^{-1}$ and valsartan of $10 \mu \mathrm{g} \cdot \mathrm{ml}^{-1}$ ). \%Coefficient of variation $(\mathrm{CV})$ of 1.688 and 1.450 was observed for valsartan and metformin respectively. Data is shown in Table 1.

\section{Linearity}

The linearity of valsartan and metformin API were calculated by plotting calibration curve keeping peak of area on $\mathrm{Y}$-axis against respective concentrations on $\mathrm{X}$ - 
Table 3 Accuracy: valsartan-metformin

\begin{tabular}{|c|c|c|c|c|c|c|c|c|c|c|c|}
\hline \multicolumn{6}{|c|}{ Accuracy of valsartan } & \multicolumn{6}{|c|}{ Accuracy of metformin } \\
\hline $\begin{array}{l}\text { Conc. } \\
\left(\mu \mathrm{g} \cdot \mathrm{ml}^{-1}\right)\end{array}$ & $\begin{array}{l}\text { Calculated Conc. } \\
\left(\mu \mathrm{g} \cdot \mathrm{ml}^{-1}\right)\end{array}$ & $\begin{array}{l}\% \\
\text { Recovery }\end{array}$ & Mean & SD & $\begin{array}{l}\% \\
\mathrm{CV}\end{array}$ & $\begin{array}{l}\text { Conc. } \\
\left(\mu \mathrm{g} \cdot \mathrm{ml}^{-1}\right)\end{array}$ & $\begin{array}{l}\text { Calculated Conc. } \\
\left(\mu \mathrm{g} \cdot \mathrm{ml}^{-1}\right)\end{array}$ & \%Recovery & Mean & SD & $\% \mathrm{CV}$ \\
\hline & 4.510 & 90.2 & 90.06 & 0.500 & 0.555 & & 15.160 & 101.07 & 101.20 & 0.11 & 0.100 \\
\hline \multirow[t]{3}{*}{5} & 4.480 & 89.6 & & & & 15 & 15.190 & 101.27 & & & \\
\hline & 4.520 & 90.4 & & & & & 15.190 & 101.27 & & & \\
\hline & 10.100 & 101.0 & 101.0 & 0.680 & 0.670 & & 32.340 & 107.80 & 107.06 & 0.780 & 0.730 \\
\hline \multirow[t]{3}{*}{10} & 10.170 & 101.7 & & & & 30 & 31.880 & 106.27 & & & \\
\hline & 10.030 & 100.3 & & & & & 32.130 & 107.10 & & & \\
\hline & 15.070 & 100.46 & 100.04 & 0.40 & 0.420 & & 48.980 & 108.840 & 109.00 & 0.156 & 0.143 \\
\hline \multirow[t]{2}{*}{15} & 14.950 & 99.67 & & & & 45 & 49.060 & 109.020 & & & \\
\hline & 15.000 & 100.0 & & & & & 49.120 & 109.15 & & & \\
\hline
\end{tabular}

Conc, concentration; $\mu \mathrm{g} \cdot \mathrm{ml}^{-1}$, microgram per milliliter; \%, percentage; SD, standard deviation; \% CV, the percentage of coefficient of variation

axis which was found to be in the linearity range between 2 and $20 \mu \mathrm{g} \cdot \mathrm{ml}^{-1}$ for valsartan, whereas the linearity for metformin was observed between 3 to $100 \mu \mathrm{g} . \mathrm{ml}^{-1}$ for metformin (Fig. 4a, b). The respective linear regression equation was recorded as $\mathrm{y}=1582 \mathrm{x}+$ 408.85 for valsartan, whereas $y=184.2 x+322.40$ for metformin. Other parameters such as intercept, \%RSD, and slope were calculated for the study which is presented in Table 2.

\section{Accuracy}

Accuracy is the recovery of each drug (valsartan and metformin) analytes at $80 \%, 100 \%$, and $120 \%$ of mentioned concentrations which were found to be on an average $\mathbf{9 7 . 0 3 \%}$ for valsartan and $105.75 \%$ for metformin. The recovery values obtained for both valsartan and metformin are in the acceptable range of 90 to $110 \%$ as per the reports available in literature [25]. It is worthy to note that the recovery values obtained in this study are also similar to the ones reported by us earlier for the RP-HPLC method development of valsartan and gliclazide [19]. The data is shown in Table 3.

\section{Precision}

Value of 0.38 and $0.65 \%$ RSD was achieved for valsartan and metformin respectively in the intraday experiment (Table 4). Value of 0.306 and $0.466 \%$ of relative standard deviation observed for valsartan and metformin respectively in inter-day experiments (Table 5).

\section{LOQ and LOD}

Value of $0.329-0.999 \mu \mathrm{g} \cdot \mathrm{ml}^{-1}$ was observed as LOD and LOQ for valsartan, and value of $0.008-0.027 \mu \mathrm{g} \cdot \mathrm{ml}^{-1}$ was observed as LOD and LOQ for metformin. The data thus obtained proved the sensitivity of the method. Broad range of concentrations of analytes of valsartan and metformin can be estimated using the developed method. The data is presented in Table 2 .

\section{Specificity and robustness}

During the RP-HPLC run of valsartan and metformin API, no additional or extra peaks were found. Hence, there was no interference from any other reagents used in the procedure. The mean $(n=6)$ percentage of coefficient of variation of robustness for valsartan was 1.17

Table 4 Method precision: metformin-valsartan

\begin{tabular}{lll}
\hline S. No. & Metformin $\left(\mathbf{3 0} \boldsymbol{\mu g} \cdot \mathbf{m l}^{-\mathbf{1}}\right)$ area & Valsartan $_{(\mathbf{1 0}} \boldsymbol{\mu g} \cdot \mathbf{m l}^{-\mathbf{1})}$ area \\
\hline 1 & 6230.00 & 16058.00 \\
2 & 6240.00 & 16104.00 \\
3 & 6250.00 & 16207.00 \\
4 & 6148.00 & 16191.00 \\
5 & 6172.00 & 16112.00 \\
6 & 6218.00 & 16197.00 \\
Standard deviation & 40.62 & 61.649 \\
Mean & 6210 & 16145 \\
\%RSD & $\mathbf{0 . 6 5}$ & $\mathbf{0 . 3 8}$
\end{tabular}

$\mu_{\text {g. } . \mathrm{ml}^{-1}}$, microgram per milliliter; SD, standard deviation; \%RSD, the percentage of relative standard deviation 
Table 5 Intermediate precision of valsartan and metformin

\begin{tabular}{|c|c|c|c|c|c|c|c|c|}
\hline \multirow{3}{*}{$\begin{array}{l}\text { No. of } \\
\text { injections }\end{array}$} & \multicolumn{4}{|c|}{ Metformin $\left(30 \mu \mathrm{g} \cdot \mathrm{ml}^{-1}\right)$ area } & \multicolumn{4}{|c|}{ Valsartan $\left(10 \mu \mathrm{g} \cdot \mathrm{ml}^{-1}\right)$ area } \\
\hline & \multicolumn{4}{|c|}{ Days } & \multicolumn{4}{|l|}{ Days } \\
\hline & 1 & 2 & 3 & Average & 1 & 2 & 3 & Average \\
\hline 1 & 6218.0 & 6111.0 & 6105.0 & 6145.0 & 16126.0 & 16010.0 & 15994.0 & 16043.0 \\
\hline 2 & 6128.0 & 6221.0 & 6215.0 & 6188.0 & 16172.0 & 16156.0 & 16040.0 & 16122.0 \\
\hline 3 & 6218.0 & 6131.0 & 6225.0 & 6191.0 & 16175.0 & 16158.0 & 16142.0 & 16158.0 \\
\hline 4 & 6136.0 & 6130.0 & 6123.0 & 6130.0 & 16159.0 & 16142.0 & 16126.0 & 16142.0 \\
\hline 5 & 6160.0 & 6153.0 & 6247.0 & 6187.0 & 16080.0 & 16264.0 & 16148.0 & 16164.0 \\
\hline 6 & 6206.0 & 6199.0 & 6193.0 & 6199.0 & 16165.0 & 16148.0 & 16232.0 & 16182.0 \\
\hline SD & 41.360 & 43.450 & 57.670 & 28.750 & 36.886 & 80.850 & 84.715 & 49.519 \\
\hline Mean & 6177.6 & 6157.0 & 6185.0 & 6173.2 & 16146.1 & 16146.3 & 16113.6 & 16135.1 \\
\hline RSD (\%) & 0.67 & 0.706 & 0.93 & 0.466 & 0.228 & 0.5 & 0.527 & 0.306 \\
\hline
\end{tabular}

$\mu \mathrm{g} \cdot \mathrm{ml}^{-1}$, microgram per milliliter; SD, standard deviation; \%RSD, the percentage of relative standard deviation

whereas, for metformin, it was 1.64 using column 1 . Using column 2, the values were 1.36 and 1.58 for metformin and valsartan. The data pertaining to this is presented in Table 6.

\section{Pharmacokinetic study}

\section{Effect of valsartan on metformin bioavailability}

The experiment was executed to estimate the possible effect of valsartan on metformin bioavailability, when administered simultaneously. We found that, on day 1 , the $C_{\max }$ was $25.74 \pm 0.39 \mu \mathrm{g} / \mathrm{mL}$ and $26.93 \pm$ $0.12 \mu \mathrm{g} / \mathrm{mL}$ for metformin treatment and combinations of metformin and valsartan post $2 \mathrm{~h}\left(\mathrm{t}_{\max }\right)$ administration respectively. On day 8 , the maximum plasma concentration was observed as $32.919 \pm$ $0.220 \mu \mathrm{g} \cdot \mathrm{ml}^{-1}$ and $32.610 \pm 0.099 \mu \mathrm{g} \cdot \mathrm{ml}^{-1}$ for metformin and in the mixture of metformin and valsartan post $2 \mathrm{~h}\left(\mathrm{t}_{\max }\right)$ administration respectively. On both day 1 and day 8 , the $C_{\max }$ and $t_{\max }$ values for both conditions showed no change between administration of metformin alone and in combination of metformin-valsartan. Similarly, no significant differences were observed with other measurements such as $\mathrm{AUC}_{(0-24 \mathrm{~h})}$ and $\mathrm{t}_{1 / 2}$. Comparison graphs are shown in Fig. 5 for day 1 and day 8 respectively.

\section{Effect of valsartan on gliclazide bioavailability}

Upon simultaneous administration, it was observed that on day 1 , the $C_{\max }$ was $11.54 \pm 2.14 \mu \mathrm{g} \cdot \mathrm{ml}^{-1}$ and 18.329 $\pm 0.12 \mu \mathrm{g} \cdot \mathrm{ml}^{-1}$ for gliclazide only and combinations of gliclazide and valsartan post $2 \mathrm{~h}\left(\mathrm{t}_{\max }\right)$ administration respectively whereas, on day 8 , plasma concentration was found to be $25.829 \mu \mathrm{g} \cdot \mathrm{ml}^{-1}$ which was recorded maximum and $26.93 \mu \mathrm{g} / \mathrm{mL}$ for treatment like gliclazide and gliclazide-valsartan at $2 \mathrm{~h}$ administration respectively. The maximum plasma concentration values for both conditions revealed no significant difference between administration of gliclazide and gliclazide-valsartan doses. The comparison graphs are shown in Fig. 6.

Table 6 Robustness: metformin-valsartan

\begin{tabular}{|c|c|c|c|c|}
\hline \multirow[t]{2}{*}{ S. No. } & \multicolumn{2}{|l|}{ Column 1} & \multicolumn{2}{|l|}{ Column 2} \\
\hline & Metformin $\left(30 \mu \mathrm{g} \cdot \mathrm{ml}^{-1}\right)$ & Valsartan $\left(10 \mu \mathrm{g} \cdot \mathrm{ml}^{-1}\right)$ & Metformin $\left(30 \mu \mathrm{g} \cdot \mathrm{ml}^{-1}\right)$ & Valsartan $\left(10 \mu \mathrm{g} \cdot \mathrm{ml}^{-1}\right)$ \\
\hline 1 & 29.1200 & 8.9200 & 29.0900 & 9.1200 \\
\hline 2 & 28.5700 & 9.0600 & 28.1900 & 9.0600 \\
\hline 3 & 29.8400 & 8.9900 & 28.2400 & 8.8900 \\
\hline 4 & 29.0400 & 8.8500 & 28.5400 & 8.7500 \\
\hline 5 & 28.8500 & 8.7900 & 28.4500 & 9.0900 \\
\hline 6 & 29.6400 & 9.0200 & 29.0400 & 9.0200 \\
\hline SD & 0.4800 & 0.1000 & 0.3890 & 0.1400 \\
\hline Mean & 29.1766 & 8.938 & 28.5196 & 8.9883 \\
\hline CV (\%) & 1.6400 & 1.1700 & 1.3600 & 1.5800 \\
\hline Accuracy (\%) & 97.2600 & 89.3800 & 95.3100 & 89.8800 \\
\hline
\end{tabular}

$\mathrm{\mu g} \cdot \mathrm{ml}^{-1}$, microgram per milliliter; $\pm \mathrm{SD}$, plus or minus standard deviation; \% CV, the percentage of coefficient of variation 


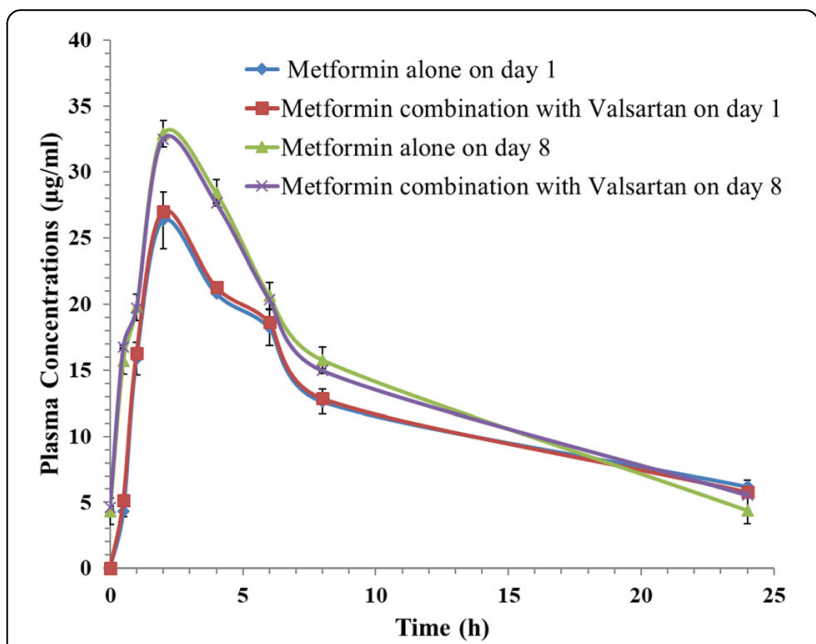

Fig. 5 Drug-drug interaction profile of metformin and valsartan $(n=$ 6). Mean plasma concentrations $\left(\mu \mathrm{g} \cdot \mathrm{ml}^{-1}\right)$

\section{Discussion}

In this study, we have focused on the effects of valsartan and gliclazide by concomitant administration in diabetic rats, as diabetes and hypertension majorly exist in elder subjects [26]. The results of our study revealed that valsartan has no effect on gliclazide during concomitant administration. An in vivo study in diabetic rat and rabbit revealed synergistic effect of gliclazide upon coadministration with pravastatin which is an antihyperlipidemic drug [22]. In addition to it, while studying the pharmacokinetic interaction between metforminvalsartan and gliclazide-valsartan, we simultaneously evaluated the effect of valsartan in healthy rats. The bioavailability of valsartan was found to be $C_{\max }$ of $3.919 \pm$ $0.030 \mu \mathrm{g} \cdot \mathrm{ml}^{-1}$ and $2.720 \pm 0.030 \mu \mathrm{g} \cdot \mathrm{ml}^{-1}$ in diabetic and healthy rats respectively at $2 \mathrm{~h}$ on day 1 . Similar results

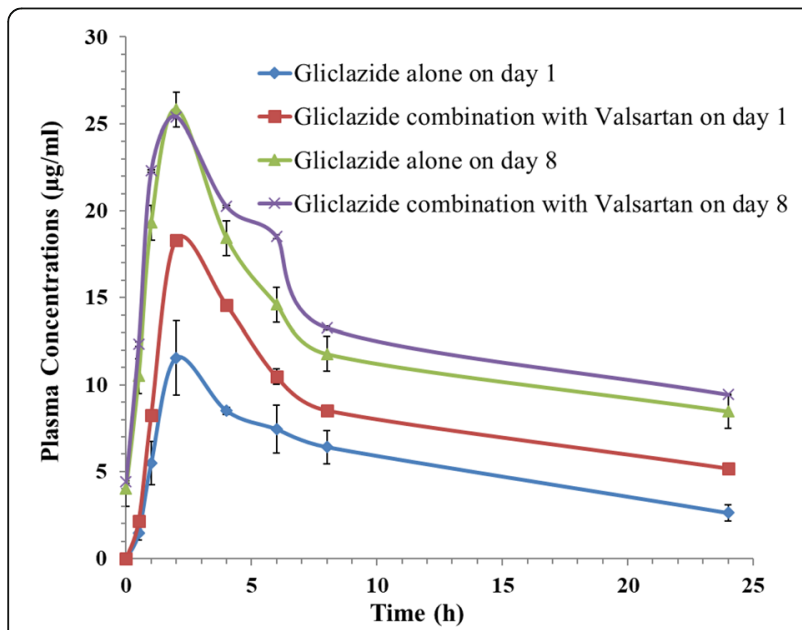

Fig. 6 Drug-drug interaction profile of gliclazide and valsartan ( $n=$ 6). Mean plasma concentrations $\left(\mu \mathrm{g} \cdot \mathrm{ml}^{-1}\right)$ were observed on day 8 . The data is presented in supplementary Fig. 1. We found that the bioavailability of valsartan did not affect metformin or gliclazide combinational treatment in hyperglycemic rats with approximately $\mathrm{C}_{\max }$ of $3-4 \mu \mathrm{g} \cdot \mathrm{ml}^{-1}$ at $2 \mathrm{~h}$ on both day 1 and day 8. The data is shown in supplementary Fig. 2 and Fig. 3. The elimination half-life, i.e., $t_{1 / 2}$ of metfor$\mathrm{min}$, is $5 \mathrm{~h}$ [27]. Drug-drug interaction of metformin with cefepime (cephalosporin, an antibiotic drug) in diabetic rat revealed reduced hypoglycemic effect of metfor$\min [28]$.

No drug-drug interaction between metforminvalsartan and gliclazide-valsartan was further confirmed by comparing the blood glucose level and found $52.36 \%$ and $64 \%$ reduction of glucose level from gliclazide and valsartan samples treated for $4 \mathrm{~h}$. Individual treatment with gliclazide showed around $54 \%$ and $62 \%$ of glucose level reduction on day 1 and day 8 respectively (data is presented in supplementary Fig. 4). Likewise reduction in glucose level was observed at $51 \%$ and $48 \%$ from combinational treatment of metformin and valsartan on the 1 st day and on 8th day respectively, whereas individual treatment on same conditions showed glucose level reduction of $55 \%$ and $54 \%$ on the 1st day and on 8th day respectively (data is presented in supplementary Fig. 5).

\section{Conclusion}

In this study, the RP-HPLC method developed and validated is robust for estimation of metformin and valsartan concurrently. Shorter run times and cost effectiveness are the advantages of the developed method. When samples are to be analyzed in bulk, the above-mentioned features are important for any RPHPLC method. No interference of any other reagents used in this procedure confirmed from the peaks of the chromatogram. We were able to analyze the plasma samples collected during pharmacokinetic study and showed that the dosage of gliclazide, metformin, and their combinational treatment with valsartan in diabetic rats did not display any drug-drug interactions in its pharmacokinetic parameters that are statistically significant. Hence, it can be concluded that polytherapy of valsartan with hypoglycemic drugs metformin and gliclazide can be advantageous and safe in patients suffering from both diabetes and hypertension.

\footnotetext{
Abbreviations

HPLC: High-performance liquid chromatography; RP-HPLC: Reversed phase high-performance liquid chromatography; FFA: Free fatty acids; PCOS: Polycystic ovary syndrome; RT: Room temperature; ICH: International Council for Harmonization; LOD: Limit of detection; LOQ: Limit of quantitation; UV: Ultraviolet; AUC: Area under the curve; RSD: Relative standard deviation
} 


\section{Supplementary Information}

The online version contains supplementary material available at https://doi. org/10.1186/s43094-021-00307-2

Additional file 1: Supplementary Fig. 1. Valsartan effect: Comparison in between normal and diabetic rats. Mean plasma concentrations $(n=6$, $\mu \mathrm{g} \cdot \mathrm{ml}^{-1}$ ).

Additional file 2: Supplementary Fig. 2. Valsartan effect on diabetic rats in presence of metformin. Mean plasma concentrations $(n=6, \mu \mathrm{g}$.ml $\left.{ }^{1}\right)$.

Additional file 3: Supplementary Fig. 3. Valsartan effect on diabetic rats in presence of Gliclazide. Mean plasma concentrations $(n=6, \mu \mathrm{g} \cdot \mathrm{ml}$ $\left.-{ }^{1}\right)$.

Additional file 4: Supplementary Fig. 4. Comparison of blood glucose level reduction between only Gliclazide and combinational administration (Gliclazide plus Valsartan) on both day 1 and 8.

Additional file 5: Supplementary Fig. 5. Comparison of blood glucose level reduction between metformin alone and combinational administration (metformin plus Valsartan) on both day 1 and 8.

Additional file 6 .

\section{Acknowledgements}

The authors sincerely thank the Vignan's University (Deemed to be), Guntur, India, for their support in conducting the research work. The data presented in this manuscript is a part of the doctoral work carried by the first author Ms. Rasmita Patra with the support and guidance of other coauthors listed in the manuscript.

\section{Authors' contributions}

$\mathrm{RP}$ executed the experiment, analyzed the data, and prepared the draft version of manuscript. YK analyzed the data and took part in the discussions. SKN has taken an active part in the discussion regarding data analysis and manuscript review. VRD supervised the study, critically reviewed the data, and edited the manuscript. All authors have read and approved the final version of the manuscript prior to submission.

\section{Funding}

This study was partly supported by a grant from SERB (ECR/2016/304). The funder had no role in study design, data collection, analysis, preparation of the manuscript, and decision to publish.

\section{Availability of data and materials}

All the data obtained from our study is available upon request, and there is no conflict of interest.

\section{Declarations}

\section{Ethics approval and consent to participate}

Animals were provided by Vijaya College of Pharmacy, Hyderabad, Telangana, India. Animal experiments and study protocols ere approved by the Institutional Animal Ethics Committee of Institutional Animal Ethical Committee (IAEC) with reference number (Registration No.: IAEC/1657/ CMRCP/T2/Ph), under CPCSEA, Delhi, India. All institutional and national guidelines for the care and use of laboratory animals were followed.

\section{Consent for publication}

Not applicable

\section{Competing interests}

The authors declare that they have no competing interests.

Received: 26 March 2021 Accepted: 10 July 2021

Published online: 03 August 2021

\section{References}

1. Ormazabal V, Nair S, Elfeky O, Aguayo C, Salomon C, Zuñiga FA (2018) Association between insulin resistance and the development of cardiovascular disease. Cardiovasc Diabetol 17(1):1-14
2. American Diabetes Association (2014) Diagnosis and classification of diabetes mellitus. Diabetes Care 37(Supplement 1):S81-S90

3. Angin Y, Beauloye C, Horman S, Bertrand L (2016) Regulation of carbohydrate metabolism, lipid metabolism, and protein metabolism by AMPK. AMP-Activated Protein Kinase 107:23-43. https://doi.org/10.1007/ 978-3-319-43589-3_2

4. Undale VR, Bhosale AV, Upasani CD (2014) Study of pharmacodynamic interaction between a polyherbal formulation BSL-150 and Metformin. Pharm Crop 5(1):67-76. https://doi.org/10.2174/2210290601405010067

5. Lee CS, Tan JHM, Sankari U, Koh YLE, Tan NC (2017) Assessing oral medication adherence among patients with type 2 diabetes mellitus treated with polytherapy in a developed Asian community: a cross-sectional study. BMJ open 7(9):e016317. https:/doi.org/10.1136/bmjopen-2017-016317

6. de Franciscis S, Gallelli L, Battaglia L, Molinari V, Montemurro R, Stillitano DM, Buffone G, Serra R (2015) Cilostazol prevents foot ulcers in diabetic patients with peripheral vascular disease. Int Wound J 12(3):250-253. https://doi.org/10.1111/iwj.12085

7. Pentikäinen PJ (1986) Bioavailability of metformin. Comparison of solution, rapidly dissolving tablet, and three sustained release products. Int J Clin Pharmacol Ther Toxicol 24(4):213-220

8. Nasri H, Rafieian-Kopaei M (2014) Metformin: current knowledge. J Res Med Sci 19(7):658-664

9. Auger C, Knuth CM, Abdullahi A, Samadi O, Parousis A, Jeschke MG (2019) Metformin prevents the pathological browning of subcutaneous white adipose tissue. Mol Metab 29:12-23. https://doi.org/10.1016/j.molmet.2019. 08.011

10. Yerevanian A, Soukas AA (2019) Metformin: mechanisms in human obesity and weight loss. Curr Obes Rep 8(2):156-164. https://doi.org/10.1007/s13 679-019-00335-3

11. Johnson NP (2014) Metformin use in women with polycystic ovary syndrome. Ann Transl Med 2(6):56. https://doi.org/10.3978/j.issn.2305-5839.2 014.04 .15

12. Ghaneei A, Jowkar A, Ghavam MRH, Ghaneei ME (2015) Cabergoline plus metformin therapy effects on menstrual irregularity and androgen system in polycystic ovary syndrome women with hyperprolactinemia. Iran J Reprod Med 13(2):93-100

13. Bensellam M, Jonas JC, Laybutt DR (2018) Mechanisms of $\beta$-cell dedifferentiation in diabetes: recent findings and future research directions. J Endocrinol 236(2):R109-R143. https://doi.org/10.1530/JOE-17-0516

14. Zhang R, Zhou X, Shen X, Xie T, Xu C, Zou Z, Dong J, Liao L (2018) Different sulfonylureas induce the apoptosis of proximal tubular epithelial cell differently via closing $K_{\text {ATP }}$ channel. Mol Med 24(1):1-8

15. Leiter LA, Shestakova MV, Satman I (2018) Effectiveness of Gliclazide MR 60 $\mathrm{mg}$ in the management of type 2 diabetes: analyses from the EASYDia trial. Diabetol Metab Syndr 10(1):30. https://doi.org/10.1186/s13098-018-0331-8

16. Mikov M, Danic M, Pavlovic N, Stanimirov B, Golocorbin-Kon S, Stankov K, Al-Salami H (2018) Potential applications of gliclazide in treating type 1 diabetes mellitus: formulation with bile acids and probiotics. Eur J Drug Metab Pharmacokinet 43(3):269-280. https://doi.org/10.1007/s13318-0170441-y

17. Passarella P, Kiseleva TA, Valeeva FV, Gosmanov AR (2018) Hypertension management in diabetes: 2018 update. Diabetes Spectr 31(3):218-224. https://doi.org/10.2337/ds17-0085

18. Moussa BA, Hashem HM, Mahrouse MA, Mahmoud ST (2018) Experimental design approach in HPLC method development: application for the simultaneous determination of Sacubitril and Valsartan in presence of their impurities and investigation of degradation kinetics. Chromatographia 81(1): 139-156. https://doi.org/10.1007/s10337-017-3425-9

19. Patra R, Reddy PN, Kumar NS, Dirisala VR (2018) Novel validated RP-HPLC method for simultaneous estimation of valsartan and gliclazide in bulk and dosage forms. Curr Pharm Anal 14(4):412-418. https://doi.org/10.2174/1 573412913666170613090348

20. AL-mohamadi AA, Ibrahim DA (2015) Possible study of drug-drug interactions between lisinopril and gliclazide in experimental animals. J Drug Discov Ther 3(33):04-12

21. Foretz M, Guigas B, Bertrand L, Pollak M, Viollet B (2014) Metformin: from mechanisms of action to therapies. Cell metab 20(6):953-966. https://doi. org/10.1016/j.cmet.2014.09.018

22. Satyanarayana S, Chandrasekhar MS, Palakshi Gouda O, Eswar Kumar K (2008) Drug-drug interaction between pravastatin and gliclazide in animal models. Sch Res Exch 2008:1-6 
23. Patel M, Kothari C (2020) Quantitative bio-analysis of pitavastatin and candesartan in rat plasma by HPLC-UV: assessment of pharmacokinetic drug-drug interaction. J Chromatogr B 1138:121962. https://doi.org/10.1016/ j.jchromb.2019.121962

24. Khalil NY, Darwish IA, Alshammari MF, Wani TA (2017) ICH guidelinescompliant HPLC-UV method for pharmaceutical quality control and therapeutic drug monitoring of the multi-targeted tyrosine kinase inhibitor pazopanib. S Afr J Chem 70:60-66

25. Shabir GA, Lough WJ, Arain SA, Bradshaw TK (2007) Evaluation and application of best practice in analytical method validation. J Liq Chromatogr Relat Technol 30(3):311-333. https://doi.org/10.1080/1082 6070601084753

26. Alanazi TO, Alenezi YM, MIO A, Alghamdi EA, Alsulami ANJ, Alzahrani AKJ, Albarqi BAM, Alotaibi SST, Owaid ZAA, Furayhan OAS, Alghanmi AH, Asiri SHY (2017) Coexistence of hypertension and diabetes mellitus in elderly population of Arar City, Northern Saudi Arabia. Egypt J Hosp Med 69(8): 3154-3159. https://doi.org/10.12816/0042867

27. Graham GG, Punt J, Arora M, Day RO, Doogue MP, Duong JK, Furlong TJ, Greenfield JR, Greenup LC, Kirkpatrick CM, Ray JE, Timmins P, Williams KM (2011) Clinical pharmacokinetics of Metformin. Clin Pharmacokinet 50(2):8198. https://doi.org/10.2165/11534750-000000000-00000

28. Ferdous S, Sultan MZ, Bashar T, Rahman A, Islam MS (2015) In vitro and in vivo studies of drug-drug interaction between metformin and cefepime. Pharm Anal Acta 6(3):348

\section{Publisher's Note}

Springer Nature remains neutral with regard to jurisdictional claims in published maps and institutional affiliations.

\section{Submit your manuscript to a SpringerOpen ${ }^{\circ}$ journal and benefit from:}

- Convenient online submission

- Rigorous peer review

- Open access: articles freely available online

- High visibility within the field

- Retaining the copyright to your article

Submit your next manuscript at $\boldsymbol{\nabla}$ springeropen.com 